\title{
Cytotoxic T-Lymphocyte Protein 4
}

National Cancer Institute

\section{Source}

National Cancer Institute. Cytotoxic T-Lymphocyte Protein 4. NCI Thesaurus. Code C17489.

Cytotoxic T-lymphocyte protein 4 (223 aa, $\sim 25 \mathrm{kDa}$ ) is encoded by the human CT LA4 gene. This protein is involved in the inhibition of T-cell mediated immune responses. 